\title{
Twin pedunculated intraoral submucosal lipoma
}

\author{
Kaushal Mahendra Shah
}

Department of Oral Medicine, Diagnosis \& Radiology, Bharati Vidyapeeth Deemed University Dental College, Sangli, Maharashtra, India

\section{Correspondence to}

Dr Kaushal Mahendra Shah, thirty2creations@gmail.com
To cite: Shah KM. BMJ Case Rep Published online: [please include Day Month Yearl doi:10.1136/bcr-2013009774

\section{DESCRIPTION}

Lipomas are well-circumscribed benign tumours and represent the most common mesenchymal neoplasm. ${ }^{1}$ Though commonly seen over trunk, shoulders, neck and axilla, it is very rare in the oral cavity. ${ }^{2}$ Although the aetiology and pathogenesis of lipomas is not well known, lipomas are thought to arise due to obesity or local growth of adipose tissue, hormonal influence during adolescence or due to chronic irritation. We describe a case of a young patient who noticed two swellings intraorally in the cheek. The patient gave a history of gradual growth of the swellings over a period of few months. They were asymptomatic, and only recently started interfering during mastication. Intraoral examination revealed two pedunculated intraoral submucosal lipomas in the right posterior buccal mucosa, having a yellowish colour, smooth surface and intact overlying epithelium (figure 1). A small erythematous area just adjacent to the molar was evident, probably due to trauma. The mobile submucosal swellings were soft and compressible, but non-tender and non-fluctuant on palpation, the larger of the two measuring about $4 \times 3 \times 3 \mathrm{~cm}$ and the smaller one about $2.5 \times 3 \times 2.5 \mathrm{~cm}$. No localised lymph node swelling was evident.

The two pedunculated growths were resected with simple excision under local infiltration anaesthesia. Histopathological examination of the excised tumours showed adult fat tissue cells

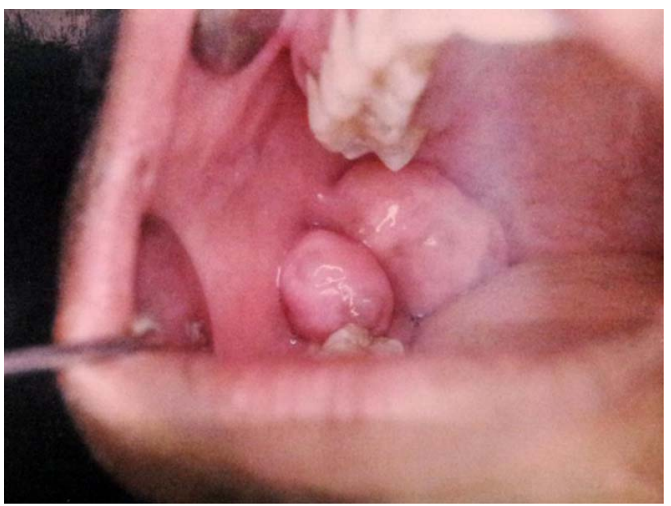

Figure 1 Intraoral photograph. embedded in a stroma of connective tissue and surrounded by a fibrous capsule, confirming the diagnosis of lipoma. Surgical excision of lipomas is the suggested treatment modality and, if adequately resected recurrence, is rare. ${ }^{3}$ Clinical awareness in diagnosis of intraoral soft tissue lesions is important as they can also be malignant, mesenchymal or salivary gland tumour.

A dental surgeon should be able to diagnose lipomas in an early stage in the maxillofacial area avoiding a massive growth of these lesions. It will be essential to prevent any aesthetic and functional disturbances in patients. An adequate treatment and postsurgical follow-up in lipomas are fundamental to re-establish the region and monitor any possible chances of recurrence.

\section{Learning points}

Other connective tissue tumours such as granular cell tumour, neurofibroma, traumatic fibroma and salivary gland lesions should be included in differential diagnosis, especially if the lipomas are larger than $3 \mathrm{~cm}$ in diameter.

- If the lipomas are not very yellow in colour, but appear pinker, chances are they are infiltrating or deep lipomas, which are more likely to recur, probably due to the difficulty of complete surgical removal. A CT scan will be a useful aid in surgical planning.

Competing interests None.

Patient consent Obtained.

Provenance and peer review Not commissioned; externally peer reviewed.

\section{REFERENCES}

1 Regezei J, Sciubba J, Jordan R. Oral pathology clinical pathologic correlations. 5th edn. Philadelphia: Saunders 2008:176-7.

2 Fregnani ER, Pires FR, Falzoni $R$, et al. Lipomas of the oral cavity: clinical findings, histological classification and proliferative activity of 46 cases. Int J Oral Maxillofac Surg 2003;32:49-53.

3 Bouquot J, Nikai H. Lesions of the oral cavity. In: Gnepp DR, ed. Diagnostic surgical pathology of the head and neck. Philadelphia: Saunders 2001:192-3. 


\section{Images in...}

Copyright 2013 BMJ Publishing Group. All rights reserved. For permission to reuse any of this content visit http://group.bmj.com/group/rights-licensing/permissions.

BMJ Case Report Fellows may re-use this article for personal use and teaching without any further permission.

Become a Fellow of BMJ Case Reports today and you can:

- Submit as many cases as you like

- Enjoy fast sympathetic peer review and rapid publication of accepted articles

- Access all the published articles

- Re-use any of the published material for personal use and teaching without further permission

For information on Institutional Fellowships contact consortiasales@bmjgroup.com

Visit casereports.bmj.com for more articles like this and to become a Fellow 